\title{
Wh+To Non-Restrictive Clauses in Polish and Related Phenomena. Part Two: Establishing the Role of to in Appositive Clauses, Adverbials and Interrogatives
}

\begin{abstract}
This paper presents a comparison between to-bearing relative clauses, adverbials and interrogatives on the one hand, vs. their to-less variants on the other, and discusses the functions associated with the presence of to. It is argued that at least three different instances of to should be distinguished. One converts relative clauses into appositive ones, which are necessarily semantically connected to the matrix clause and it makes the semantic connection override even apparent lack of appropriate syntactic connection. It attaches to relativizers, including gdzie 'where' and kiedy 'when' relative clauses. It is argued that the same segment is present in adverbials, triggering a factitive presupposition, as is the case of appositive relatives generally. The second to links the content of a kind relative, an adverbial or a $w h$-interrogative to previous contexts, possibly triggering a pragmatic presupposition. The third converts standard $w h$-interrogatives into either rhetorical or thetic questions. It is argued that while in the third instance we are dealing with a separate word and in the second with a clitic, the first to, hitherto unidentified or possibly falsely identified in relevant literature, appears to have both some characteristics of a clitic and of an affix.
\end{abstract}

\section{Keywords}

Polish relative clauses, appositive clauses, the segment to, presupposition triggers, thetic questions, rhetorical questions, clitics

\section{Streszczenie}

$\mathrm{W}$ artykule omawia się funkcje segmentu to w zdaniach względnych, zdaniach okolicznikowych i pytaniach uzupełnienia. Wykazuje się, że segment ten w wymienionych typach zdań odpowiada co najmniej trzem różnym jednostkom. Pierwsza z nich wskazuje, że mamy do czynienia ze zdaniem względnym niedefiniującym, ale koniecznie powiązanym semantycznie z treścią zdania głównego; co więcej, powoduje, iż zdania takie są akceptowalne, mimo niepoprawnej budowy składniowej. Najprawdopodobniej ten sam element może być dołączony - jako wyzwalacz presupozycji - do spójnika wprowadzającego zdanie okolicznikowe miejsca i czasu. Druga jednostka to wykładnik nawiązania, być może 
związany z presupozycją pragmatyczną, obecna w pytaniach uzupełnienia i w zdaniach względnych utożsamiająco-uogólniających. Trzecia jednostka natomiast, pojawiająca się w pytaniach, przekształca je w pytania retoryczne lub tetyczne. O ile ta ostatnia jednostka ma status wyrazu, o tyle wykładnik nawiązania wykazuje wszelkie własności wiązane z klitykami. Status pierwszej jednostki jest problematyczny, jako że wykazuje zarówno cechy klityki, jak i afiksu.

\section{Słowa kluczowe}

zdania względne w języku polskim, zdania niedefiniujące, segment to, wyzwalacze presupozycji, pytania tetyczne, pytania retoryczne, klityki

\section{Introduction}

In Part One of the paper, I have presented an overview of Polish relative clauses with and without to. I have argued that Polish possesses not only restrictive and appositive relative clauses, but also two types of relative clauses of the 'third kind', i.e. degree relatives and kind relatives (cf. Grosu and Landman 1998 for theoretical approaches; Buttler et al. 1971 and Przepiórkowski et al. 2002 for kind relatives in Polish). I have also shown that among non-restrictive relative clauses one can find two types of pseudo-relative clauses: one that describes a simultaneous event (cf. Cinque 1996) and one that describes a consecutive event. I have also argued that when to is introduced after the relativizer który in a non-restrictive clause, it converts the clause into an appositive one.

In this part, a fine-grained distinction between to-bearing and to-less appositive clauses is discussed (Section 4). Section 5 broadens the scope of inquiry and discusses the role of to in clauses with relativizers kiedy 'when' and gdzie 'where'. Section 6 presents an overview of the impact of to on relative clauses and presents a preliminary conclusion. In Section 7, the discussion is extended to cover the role of to in $w h$-adverbials and wh-interrogatives. Part Two ends with a Conclusions section, in which the possibility of linking the observed effects to a single element to is discussed. The numbering of sections and examples is continuous for both parts.

\section{Który and który to in appositive relative clauses: a closer look}

Given the fact that the presence of the segment to after który mainly disables a non-appositive reading of relative clauses, it is not surprising that it does not negatively affect the acceptability of true appositive clauses (with one exception, discussed below). Interestingly, it almost does not alter their behavior in diagnostic contexts for unintegrated appositives, as can be seen by comparing 
Citko's (2016) examples with their modified to-bearing counterparts, though it enhances acceptability in less straightforward situations.

\section{Heavy pied-piping}

Some pied-piped constructions are not affected by to:

(59) Zaprosiliśmy naszego byłego prezydenta, popularność wykładów którego (to) była imponująca.

'We invited our former president, the popularity of whose lectures was quite impressive.'

(adapted from Citko 2016: 89)

Yet, when heavy pied piping is associated with a morphological mismatch between the head and the relativizer, which can be seen in the approximate Polish renderings of Cinque's original example, repeated here as (60), given in (61) and (62), the presence of to improves acceptability:

(60) Giorgio non era certo un romanziere, la prima virtù dei quali è quella di catturare l'interesse del lettore.

'G. was no novelist (sing.), the first virtue of whom (pl.) is that of catching the reader's interest.'

(61) ?Jerzy z pewnościa nie był powieściopisarzem, największq zaleta których ma być zafascynowanie czytelnika.

(62) Jerzy z pewnościa nie był powieściopisarzem, największa zaleta których to ma być umiejętność zainteresowania czytelnika.

\section{Non adjacency to the head}

Also the non-adjacent appositive relative clause is slightly improved with to, though - given some constraints, possibly of semantic nature yet to be understood (cf. Cinque 2008: 103) - some examples of non-adjacent relative clauses may appear doubtful. Such is the case of Citko's (2016, (7)) example, which in her paper serves as evidence for the presence of non-adjacent appositive clauses in Polish.

(63) Odkąd Kowalscy wyjechali, których nikt nie zaprosit, mamy święty spokój.

'Since the Kowalskis left, who no one invited, all is quiet.'

(Citko 2016: (7))

However, I find both her original version, quoted above, and a to-appended version (64) rather awkward, unless the relative is introduced as a sort of parenthetical afterthought in a spontaneous spoken discourse (cf. Guz 2017). ${ }^{1}$

\footnotetext{
${ }^{1}$ I am indebted to Ewa Willim for that observation.
} 
(64) ?Odkąd Kowalscy wyjechali, których to nikt nie zaprosit, mamy święty spokój.

Much more telling effects are obtained with Polish rendering of Cinque's (2008: 103) original example in (65):

(65) Da quando i russi se ne sono andati, i quali non si erano mai veramente integrati con la popolazione, la pace è finite.

'Since the Russians left, who had never really mixed with the population, there is no more peace.'

The direct rendering of (65) in Polish, is awkward, as shown in (66), and it is not much improved by appearance of to, as (67) demonstrates:

(66) ?Odkąd Rosjanie wyjechali, którzy nigdy naprawdę nie integrowali się z ludnością, nie ma już spokoju.

(67) ?Odkąd Rosjanie wyjechali, którzy to nigdy naprawdę nie integrowali się z ludnościa, nie ma już spokoju.

However, if the matrix clause is modified to say that peace has finally reigned after the Russians left, there is a notable rise in acceptability when to is added.

(68) ?Odkąd Rosjanie wyjechali, którzy nigdy naprawdę nie integrowali się z ludnościa, zapanowat spokój.

'Since the Russians left, who had never really mixed with the population, peace has reigned.' (transl. JL-U)

(69) Odkąd Rosjanie wyjechali, którzy to nigdy naprawdę nie integrowali się z ludnością, zapanowat spokój.

The difference in acceptability between (68) and (69) is crucial to my proposed analysis of the function of the segment to, and will be elaborated upon later.

\section{Split antecedents}

Sentences with split antecedents are awkward, and subject to some restrictions. Citko (2016: (8)) gives the example adapted from English, about people eating different kind of cakes.

(70) Jan lubi pączki, a Maria woli rogaliki, które $_{\mathrm{i}+\mathrm{j}}$ jedzą z masłem.

'Jan likes doughnuts, but Maria prefers croissants, which they eat with butter.' (Citko 2016: (8))

Interestingly, there is no difference in acceptability between the to-less (70) and the to-bearing (71):

(71) Jan lubi pączki, a Maria woli rogaliki, które $_{\mathbf{i}+\mathbf{j}}$ to jedzq̨ z masłem. 
However, I would argue that the reading upon which który refers both to doughnuts and croissants is coerced ${ }^{2}$ here by the plural verb in the matrix clause, which enhances an ad sensu interpretation, according to which each of the protagonists eats their favorite cake. I will show below that when the semantically coercive element is removed, the situation changes dramatically. In addition, adjacency of plural które to grammatically plural noun rogaliki, 'croissants' makes (70) and (71) grammatically correct, though the normatively construed sense would have both Jan and Maria eat croissants with butter, despite Jan's culinary preference. The importance of apparent grammaticality in acceptability judgments may explain why such split antecedent constructions are possible in Polish, and others are not. For example, Cinque's Italian example (39), repeated here for convenience, cannot be rendered in Polish, either with or without to:

(39) Se Carlo non amava più Anna, $i$ quali ${ }_{i+j}$ d'altra parte non si erano mai voluti veramente bene, una ragione c'era.

'If Carlo was no longer in love with A., who at any rate never really loved each other, there was a motive.' (Cinque 2008: 104)

(72) ${ }^{*}$ Jeżeli Karol nie kochał już Anny, którzy (to) skądinąd nigdy się nie kochali, był to motyw.

Yet within the doughnut vs. croissant scenario it is possible to come up with a pair of examples in which the presence of to does improve acceptability:

(73) ^Jan kupił pączka, a Maria rogalika, które przybrano lukrem.

'Jan bought a doughnut and Maria a croissant, [both of] which had been decorated with icing.'

(74) Jan kupił pączka, a Maria rogalika, które to przybrano lukrem.

Here again the difference in acceptability between (73) and (74) is crucial to my proposed analysis of the function of the segment $t o$, and will be elaborated upon later.

\section{Mismatches in illocutionary force}

In such cases the addition of to renders the sentence more natural (compare (75) with (76)):

(75) To jest nowy prezydent, dla którego natychmiast znajdź miejsce!

'This is the new president, for whom find a place immediately'.

(Citko 2016: (6a))

(76) To jest nowy prezydent, dla którego to natychmiast znajdź miejsce!

${ }^{2}$ The term coercion is used here accordingly to Lauwers and Willems (2011). 


\section{Temporal heads}

Citko (2016: 92) rightly notes that który appositive relatives "are degraded with temporal heads", providing the following example as evidence:

(77) ?*W zeszłym roku, w którym Jan się urodzit, było bardzo ciepło.

in last year in which Jan REFL was born was very warm

'Last year, when Jan was born, was very warm.' (Citko 2016: (17))

Adding to improves (77)'s acceptability only slightly, if at all, as can be seen in (78):

(78) ??W zeszłym roku, w którym to Jan się urodził, było bardzo ciepło.

What seems to partly salvage both (77) and (78) is the syntactic parallelism between the adverbial within the matrix clause and the relativizer, since both are parallel prepositional phrases, thus having the relativizer apparently match the noun within the adverbial. Without a prepositional phrase in the adverbial the sentence is degraded, as can be seen in (79):

(79) ${ }^{*}$ Zeszłego lata, $\boldsymbol{w}$ którym (to) Jan się urodził, było bardzo ciepło.

LastGEN summerGEN in which Jan REFL was born was very warm

'Last summer, when Jan was born, (it) was very warm.' (transl.JL-U)

In addition, syntactic parallelism in case alone between adverbial and relativizer does not prevent the sentence from being degraded, as can be seen in (80):

(80) *Zeszłego lata, którego (to) Jan się urodził, było bardzo ciepło.

lastGEN summerGEN whichGEN Jan refl was born was very warm

Actually, Cinque's original example in (81) structurally resembles (80), since both (80) and (81) bear no apparent prepositional phrase the syntax of which can be mirrored in the relative:

(81) ${ }^{\star}$ La settimana prossima, la quale sono in ferie, ti vengo a trovare.

'Next week, which I am on holidays, I will come and visit you.'

(Cinque 2008: 108)

Yet, curiously, it is the presence of the preposition in the temporal head that plays an important role in acceptability of examples (77)-(80). While (79) and (80), which have the temporal head in the genitive, are unacceptable, with (77) and (78) the judgment is less straightforward. In addition, if the prepositional phrase within the adverbial, matched by the prepositional phrase in the relative, contains an expression that is not a frozen or semi-frozen structure (as is the case in (77) and (78)), the insertion of to seems to prevent the degradation. If a calendar year is substituted as for zeszly 'last' and follows the noun rok 'year', the to-less version (82) becomes marginally acceptable, and the to-bearing version - fully acceptable: 
(82) ?W roku 1985, w którym Marta się urodziła, mleko w proszku było na kartki.

'In the year 1985, when Marta was born, powdered milk could be only bought with coupons. ${ }^{3}$

(83) W roku 1985, w którym to Marta się urodziła, mleko w proszku było na kartki.

Interestingly, this is the case of expressions in which the numeral follows the noun. In reverse order both versions are far less felicitous, but the to-bearing relative is marginally better:

(84) ${ }^{*}$ W 1985 roku, $\boldsymbol{w}$ którym Marta się urodziła, mleko w proszku było na kartki.

(85) ?W 1985 roku, w którym to Marta się urodziła, mleko w proszku było na kartki.

There are several tentative explanations for the differences observed between (82) and (83) on the one hand and (84) and (85) on the other. The simplest one is that numeral-first unmarked pattern is closer to semi-frozen structures, while the reversed pattern, being marked, is not. That would account for the parallel behavior of (77)-(78) and (84)-(85) respectively. However, the difference between numeral-first pattern and noun-first pattern may be related to the overall differences between preposed and postposed attributes in Polish. When the attribute is post-posed it acquires either a 'class-establishing' meaning (traditionally called 'classificatory' (as opposed to 'property-denoting' meaning, traditionally called 'qualitative') (Linde-Usiekniewicz 2016b), or - with an appropriate intonation pattern - a contrastive character (Linde-Usiekniewicz 2008: 260). If that were the case, it could be argued that the improvement in acceptability is due to marking the relative clause as unequivocally appositive, thus avoiding a possible mismatch between specific antecedents and a possibly restrictive reading of the relative.

The observations presented so far in this section focused on the positive impact of the segment to in appositive relative clauses. However, there are instances in which the segment in question degrades the acceptability. Such is the case of semantically unrelated, i.e. parenthetical, appositive relative clauses. Thus while (46), repeated here for convenience is quite acceptable, its to-bearing variants are not unless we envisage a situation in which the feature of being born on a Friday, or dressing in pink, or running in marathons is pragmatically related to one's academic choices:

(46) Janek, który urodził się w piątek//ubiera się na różowo//biega w maratonach//...//, studiuje matematykę.

'John, who was born on a Friday//dresses in pink//runs in marathons//..., studies mathematics.' (transl. JL-U)

\footnotetext{
${ }^{3}$ In Poland at that time, baby formulas were made from powdered milk, rather than bought ready-made.
} 
(86) *Janek, który to urodził się w piątek, studiuje matematykę.

'John, who was born on a Friday, studies mathematics.' (transl. JL-U)

(87) *Janek, który to ubiera się na różowo, studiuje matematykę.

'John, who dresses in pink, studies mathematics.' (transl. JL-U)

(88) *Janek, który to biega w maratonach, studiuje matematykę.

John, who runs in marathons, studies mathematics.' (transl. JL-U)

To sum it up: the addition of to to appositive relative clauses is not neutral, as it affects their acceptability either positively or negatively. The acceptability can be improved when the syntactic pattern associated with unintegrated appositive relative clauses goes against standard morphosyntax of relative clauses, i.e. in the case of split antecedents (cf. (74)), heavy pied piping together with morphological mismatch between the antecedent and the relativizer (cf. (62)), non-adjacency to the head (cf. (69)) and temporal heads (cf. (83)).

In addition, with non-adjacent head it is necessary for the purport of the relative to be such that it can be partly causally related to the purport of the matrix clause. This is clear in the Polish version of the 'Russians scenario' in (69). ${ }^{4}$ If the Russians remained unintegrated with the population, it is quite easy to imagine how their leaving could have contributed to the restoration of peace, but quite difficult to imagine how their leaving could have fomented the unrest.

On the other hand, a semantic relation between the purport of the appositive relative clause and the matrix is necessary for który to clauses. It can be quite vague, as in the place for the new president scenario in (76). Nevertheless, the addition of a to segment to an appositive relative clause unrelated to the matter at hand either degrades it or imposes the reading under which the purport of the relative is relevant to the discourse, i.e.is at-issue.

\section{Other wh and who to relativizers}

As already mentioned in Introduction in Part One, relative clauses can also be introduced by kiedy 'when' and gdzie 'where'. When to is added to kiedy, the only reading available is appositive, e.g. in (89), which is a to-modified version of (12) from Part One.

(89) Tęsknię za czasami, kiedy to $z$ wakacji przywoziło się rolke filmu ORWO 36x24. (NKJP)

'I miss the times when one used to bring back a roll of ORWO film 36x24 from one's holidays.' (transl. JL-U)

${ }^{4}$ The analysis presented here may be not appropriate for the original Italian sentence (65). 
Moreover, temporal relativizer kiedy, both with and without to, is acceptable in appositive relative clauses with temporal heads, e.g.:

(90) W zeszłym roku, kiedy (to) Jan się urodził, było bardzo ciepło.

'Last year, when Jan was born, was very warm.' (transl. JL-U)

(91) Zeszłego lata, kiedy (to) Jan się urodzit, było bardzo ciepło.

'Last summer, when Jan was born, (it) was very warm.'

In (90) and (91) the presence of to enhances the appositive reading (the restrictive reading is blocked by determined character of the temporal adverb in the matrix clause).

Gdzie relative clauses can in fact be either appositive or restrictive. With to added to a relative clause, the reading becomes uniquely appositive, as in (92), which is a to-modified version of (13) from Part One:

(92) Na zakończenie sezonu mamy jakieś lampki wina, sa kraje, gdzie to wino podaje się do kolacji, nawet wśród sportowców. (NKJP)

'To end the season glasses of wine are served, there are countries, where wine is served with dinner, even among the athletes.' (transl. JL-U)

Interestingly, gdzie can substitute for który in consecutive pseudo-relatives, maintaining the same ambiguity, given an appropriate sentential context:

(93) Weszli do pokoju, gdzie rozpoczęto rozmowę.

'They entered a/the room, where the conversation began.' (transl. JL-U)

Consecutive reading: they $y_{i}$ entered the room where they started the conversation

'They entered a/the room where the conversation had begun.' (transl. JL-U)

Restrictive reading: they ${ }_{1}$ entered the room where they ${ }_{j}$ had started the conversation

'They entered the room, where the conversation had begun.' (transl. JL-U)

Appositive reading: they, entered the room, where they ${ }_{I}$ had started the conversation

When the matrix clause is negated, only appositive and restrictive interpretations are available, i.e.:

(94) Nie weszli do pokoju, gdzie rozpoczęto rozmowę.

'They did not enter the room where the conversation had begun.' (transl. JL-U)

Restrictive reading: they ${ }_{1}$ did not enter the room where they ${ }_{2}$ had begun the conversation

'They did not enter the room, where the conversation had begun.' (transl. JL-U)

Appositive reading: they ${ }_{1}$ did not enter the room, where they ${ }_{2}$ had begun the conversation

When to is added, the restrictive meaning is blocked, as in the który to version, and the consecutive pseudo-relative reading seems doubtful unless 
both the appositive and the consecutive readings seem conflated into one, i.e. (95) is interpreted as 'theyi entered the room, where theyr began the conversation. ${ }^{5}$

(95) Weszli do pokoju, gdzie to rozpoczęto rozmowę.

Appositive reading: they ${ }_{i}$ entered the room, where they ${ }_{j}$ had begun the conversation ??Consecutive reading: they $y_{i}$ entered a/the room where they ${ }_{i}$ began the conversation

\section{The role of to in relative clauses: interim conclusion}

The observations presented in the two previous subsections of this section show that to can appear in appositive relative clauses, either introduced by $k t o ́ r y$, including relatives with internal heads, and in appositive relative clauses introduced by gdzie, kiedy, but not in corresponding non-appositive ones. In all these instances the presence of to signals that the purport of the relative clause is at-issue, and not parenthetical to the matter at hand.

In jaki kind relatives the presence of to is subject to very specific semantic constraints: the antecedent noun needs to be used predicatively. In such contexts the presence of to indicates that the qualities to which the kind relative refers have already been introduced, possibly indirectly, in the universe of the discourse.

Thus the observations presented in Sections 4 and 5 may preliminarily serve as evidence for two alternative proposals. If the claim is made that który to is a separate lexeme different from który, in line with Mendoza (2010: 7), it is necessary to postulate the existence of at least two, if not more lexemes that function as relativizers: kiedy to, gdzie to and possibly jaki to as well as co to. On the other hand, the presence of both to-bearing and to-less variants can be seen as evidence in favor of postulating the existence of a morpheme, or possibly a lexeme to that can attach to relativizers.

However, to further evaluate both proposals, it is necessary to pay attention to the appearance of to outside relative contexts. Since the main topic of this paper is relativizers bearing to, the analysis of non-relative contexts will be restricted to those in which elements homonymous with relativizers appear.

\footnotetext{
${ }^{5}$ In fact, they are not conflated, but to enforces the reading of the content of the consecutive as presupposed. See Section 7 below for more detailed treatment of presupposition triggering by to.
} 


\section{Wh-to in non-relative contexts}

\subsection{The segment to with conjunctions introducing adverbial clauses}

Temporal adverbial clauses introduced by kiedy and $g d y$ 'when' are relatively well represented in the National Corpus. Adverbials of place with gdzie are quite rare and most $g d z i e$ subordinate clauses are in fact relative, correlative or pseudo-relative.

The apparent lack of naturalistic data containing adverbials with kiedy to, gdy to and kiedy to does not mean that they are impossible. Some NKJP examples can be to-modified, though most likely they would not be possible in the original contexts. In order to identify the role of to in such clauses, it is necessary to contrast to-less and to-bearing variants.

In the case of (96) the original text suggests that going to bed mentioned in the adverbial clause was not a straightforward matter and there must have been something, possibly the anxiety, preventing the protagonist from doing it. This suggestion is encoded by the presence of the adverb już, rendered as 'finally' in the gloss.

(96) Niepokoiło go to zagadnienie i długo nie mógł zasnać, kiedy się już położył do łóżka. (NKJP)

'This question made him anxious and he could not fall asleep when he finally had gone to bed.' (transl. JL-U)

This suggestion disappears if $j u \dot{z}$ is removed, as is done in (97):

(97) Niepokoiło go to zagadnienie i długo nie mógł zasnać, kiedy położył się do łóżka. ${ }^{6}$ 'This question made him anxious and he could not fall asleep for a long time when he had gone to bed.' (transl. JL-U)

However, if kiedy to, instead of kiedy, is introduced into a clause without już, as in (98), the fact that going to bed has not been straightforward is again suggested.

(98) Niepokoiło go to zagadnienie i długo nie mógł zasnać, kiedy to położył się do łóżka.

A similar case can be made for (99) and (100):

(99) [A Mumia lubił niezmienność[,] sytuacje bez niespodzianek.] Dlatego zdziwił się nieprzyjemnie, kiedy drzwi od dobudówki, którą Rugby nazywat „zapleczem”, otworzyt nie sam właściciel, lecz jakiś duży blondyn z rumieńcami na twarzy i rzadkimi kręconymi włosami. (NKJP)

\footnotetext{
${ }^{6}$ For euphonic reasons się is transposed in (97) and (98).
} 
'[And the Mummy liked immutability, no-surprise situations.] That is why he was unpleasantly surprised when the door to the extension, which Rugby called "the back", was opened not by the owner himself, but by a big blond man with a ruddy face and thin curly hair.' (transl. JL-U)

(100) Dlatego zdziwił się nieprzyjemnie, kiedy to drzwi od dobudówki, którą Rugby nazywał „zapleczem”, otworzył nie sam właściciel, lecz jakiś duży blondyn z rumieńcami na twarzy i rzadkimi kręconymi włosami.

Here the to-modified variant suggests that opening of the door is somehow linked to previous discourse or otherwise present in the discourse's universe.

A similar phenomenon can be observed in sentences with adverbials of place. In the original version (101), separated from its context, the adverb przedtem 'earlier', though it informs the audience about the protagonist having gone back to the seat he occupied previously, does not necessarily link the sentence to previous discourse:

(101) Siada $z$ powrotem, gdzie siedział przedtem, $z$ daleka od niej.

' $(\mathrm{He})$ sits back where he was sitting earlier, away from her'. (NKJP)

By contrast, in the modified version in (102), there is a strong suggestion that the former place occupied by the protagonist has been mentioned in the previous discourse, or is otherwise known to the audience, and is somehow relevant to the development of the story arc:

(102) Siada z powrotem, gdzie to siedział przedtem, $z$ daleka od niej.

More importantly, besides linking to previous discourse and signaling that the speaker assumes some previous knowledge on the part of their audience, temporal conjunctions with to act as presupposition triggers (cf. Levinson 1983: 181). ${ }^{7}$ This can be seen when (97) is modified to refer to the future. While (103) does not presuppose the protagonist finally going to bed, (104) does.

(103) Zaniepokoi go to zagadnienie i długo będzie mógł zasnąć, kiedy położy się do łóżka. 'This question will make him anxious and he will not be able to fall asleep when he goes to bed.' (transl. JL-U)

(104) Zaniepokoi go to zagadnienie i długo będzie mógł zasnąć, kiedy to położy się do łóżka.

${ }^{7}$ The clearest case for presupposition triggering value of to with temporal conjunctions can be made by adapting Polish renderings of Levinson's (1983: 181) examples, taken from Levinson (2010: 218-219). To is acceptable in presupposition triggering Kasia płakała zanim (to) ukończyła dysertację. 'Kasia cried before she finished her thesis' and unacceptable in presupposition cancelling context: Kasia umarła zanim ( ${ }^{*}$ to) ukonczyła dysertację. 'Kasia died before she finished her thesis.' (transl. JL-U) 
Interestingly, in the case of $g d z i e$ to adverbials, as opposed to simple gdzie adverbials, it is also possible to come by evidence that gdzie to is involved in presupposition triggering. The issue is complicated and involves a counterfactive predicate in the matrix clause. Thus in:

(105) Jan wyobrażat sobie, że śpi, gdzie Pawet się schowat.

'Jan imagined that he was sleeping where Paweł had hidden himself.' (transl. JL-U)

the presence of the counterfactive predicate wyobrażac sobie 'imagine' in the matrix clause presupposes that Jan did not really sleep but does not affect the true-value of Paweł having hidden himself somewhere. Thus it is possible to understand the sentence in two ways: on one reading Paweł's hiding place and possibly his hiding as well are figments of Jan's imagination, as is Jan's sleeping, and on the other, while Jan's sleeping remains counterfactive, Paweł's hiding is not, and the hiding space becomes specific. ${ }^{8}$ By contrast, if $g d z i e$ to is substituted for gdzie, the counterfactuality no longer spreads to the adverbial, and only the second reading available in $g d z i e$ alone version is possible:

(106) Jan wyobrażał sobie, że śpi, gdzie to schował się Paweł. ${ }^{9}$

Thus, the presence of to after conjunctions in $w h$-adverbials works along similar lines to those observed for relative clauses: it links the adverbial to previous discourse or audience's previous knowledge, thus suggesting the existence of pragmatic presupposition, and importantly, triggers the presupposition the way appositive relative clauses do.

\subsection{Wh-to and wh to-less interrogatives}

Even a cursory corpus query reveals that interrogative sentences can bear to after an interrogative pronoun. Some of the corpus examples represent rhetorical questions, e.g.: ${ }^{10}$

(107) Kiedy to wreszcie Państwowa Inspekcja Pracy i Sanepid skontroluja kolej?

'When will the Chief Labor Inspectorate and the Sanitation and Health Department finally inspect the railway?'

(108) Od kiedy to akt wykonawczy wchodzi w życie przed ustawodawczym - zauważa. "Since when does the executive legislation come into force before the [respective] legislative act [does]?", he observes.' (transl. JL-U)

${ }^{8}$ The counterfactive reading of Pawel's hiding is voided in a parallel correlative structure: Jan wyobrażat sobie, że śpi tam, gdzie Pawet się schowat. 'lit. Jan imagined that he was sleeping there where Paweł had hidden himself' (transl. JL-U). I am indebted to Ewa Willim for that observation.

9 The word order is transposed to make it clear that the to here is not a 'rhematic' to (cf. Wiśniewski 1990, Huszcza 1986, and Linde-Usiekniewicz 2016a among others).

${ }^{10}$ See Han (2002) for wh-questions as rhetorical questions. 
Here the rhetoric character of the question is additionally marked by the direct speech framing verb zauważa. Yet, if the direct speech framing verb is removed, it is the presence of to alone that imposes the rhetorical reading: ${ }^{11}$

(109) Od kiedy to akt wykonawczy wchodzi w życie przed ustawodawczym?

'Since when does the executive legislation come into force before the legislative act [does]?'(transl. JL-U)

However, the original Mendoza's example in (5a) is not a rhetoric question:

(5a) A doką to idziesz? (Mendoza 2010: 8)

'And where are you going?' (transl. JL-U)

In addition, if a procedure similar to the one applied to (96) is carried out, i.e. items that may contribute to the observed meaning besides to are removed, several pertinent observations can be made. First of all, at first glance the difference at the 'speaker's setting level' identified by Mendoza's informant may be attributed both to the presence of to and to the initial particle $a$ 'and' (since both are absent in the contrasted straightforward question). Yet it is not the case, since the same effect (which will be specified in detail below) is maintained with to alone, and not with initial $a$ 'and' alone:

\section{(110) Dokąd to idziesz?}

Secondly, the speaker's setting in question translates to their surprise at seeing the addressee being on the move. For such a reading to be available the question has to be asked when actually encountering the addressee going someplace. This becomes obvious when the goal interrogative is changed into the temporal one, e.g.:

(111) \#Kiedy to idziesz?

lit. 'When are you going?'

Since the temporal interrogative blocks the observational setting, the question is pragmatically incongruous.

Thirdly, the 'surprise' element associated with to actually invalidates the straightforward interrogative reading, similarly to what it does when it converts a straightforward question into a rhetorical one.

Upon closer examination the intuitively observed 'surprise' element turns out to be a result of converting an ordinary wh-question to subtype of thetic

${ }^{11}$ In fact, when (109) is produced in actual speech, it can represent yet another structure. If to is produced stressed and with a falling pitch (cf. Huszcza 1986, 2000, Wiśniewski 1990, LindeUsiekniewicz 2016a), the reading would be 'And since when it is the executive legislation that comes into force before the legislative act?' (and not: 'Since when it is that the executive legislation comes into force before the legislative act'). 
question: the standard division of a wh-question between what is presupposed in the question or constitutes its topic (i.e. datum quaestionis) and the interrogative word, bearing focus, is neutralized by the presence of $t$. As the result the question is not so much about the goal of the movement, but about the event of going anywhere at all, hence the 'surprise' effect. ${ }^{12}$

The two types of to-featuring apparent wh-questions, discussed above, share at least one feature: the presence of to disables the reading ordinarily associated with the interrogative $w h$-structures. However, there are instances in which the presence of to does not invalidate the standard interrogative reading, but rather explicitly links the question, or more precisely its datum quaestionis either to previous discourse (113) or to the extralinguistic context of its utterance (114).

(113) [Biorę dzidę i idę. - Proszę pana, a gdzie pan ma dzidę? - Nie mam dzidy jako takiej. Tylko tak mówię: biorę dzidę i idę.] - Proszę pana, a gdzie to pan tak sobie idzie? (NKJP)

'["I take a spear and go". "But sir, where is your spear?". "I don't have a spear as such. It is just a saying' (lit. I am just saying): I take a spear and go."] "Sir, and where are you going?"” (transl. JL-U)

The setting in (114) is Warsaw during WWII, and the narrator first hears gun fire and then observes people running off the streets to hide in buildings' inner courtyards (obviously to avoid being caught by the Nazis in a street roundup). He approaches a group of such people and utters (114):

(114) Gdzie to łapia, prosze państwa? - zapytałem. (NKJP)

"And where is the roundup?", I asked.' (transl. JL-U)

More examples of that kind can be constructed by adding to to existing examples, while others can be constructed, e.g.:

(115) Kiedy to pan, panie Leszku, znów wyjedzie do Polski? (adapted from NKJP)

'And when will you, Mr Leszek, go to Poland again?' (transl. JL-U)

${ }^{12}$ Mathieu (2004: 330) uses the term 'thetic question' in a similar way. For him the difference between French ordinary combien 'how many' questions, e.g.

(i) Combien de livres as-tu relus l'été dernier?

how-many of books have-you reread the-summer last

'How many books have you re-read last summer?'

and split questions, e.g.

(ii) Combien as-tu relu de livres lété dernier?

how-many have-you reread of books the-summer last

consists in (i) being "clearly about a set of books under the focus of attention", while in (ii) "the focus of attention is not a set of books. Rather, the sentence is asking about the event of rereading books."

${ }^{13}$ The playful saying in question is based on the rhyme between dzide 'spearACCUSATIVE and idę 'I go/am going.' 
For such question to be felicitous, previous trips to Poland, or future travel plans in general have to be mentioned in the previous conversation, either by the speaker or by their audience/interlocutor.

In more general terms, since the content of datum quaestionis is presupposed in its own right, the impact of to in wh-to questions would convert them into questions explicitly indicating pragmatic presupposition as well. ${ }^{14}$

Among który to interrogatives the ones that are pertinent here are those featuring a full lexical verb. ${ }^{15}$ Similarly to what has been observed for kiedy to questions, the presence of to indicates that the question, or more specifically the datum questionis part is linked to previous context or suggests that the speaker assumes some knowledge about it, e.g.:

(116) Która to z pani córek robi karierę śpiewacza, bo chyba nie ta wiecznie kaszlaca Urszula? (NKJP)

'Which of your daughters makes her career as a singer, because it cannot be the permanently coughing Ursula?' (transl. JL-U)

(117) O których to obiektach mówił pan prezydent? (NKJP)

'Which were the facilities the president was talking about?' (transl. JL-U)

If to is removed, the pragmatic presupposition is no longer in evidence, as shown in (118) and (119) compared with (116) and (117) respectively:

(118) Która z pani córek robi karierę śpiewaczą, bo chyba nie ta wiecznie kaszląca Urszula?

'Which of your daughters makes her career as a singer, because it cannot be the permanently coughing Ursula?' (transl. JL-U)

(119) O których obiektach mówił pan prezydent?

'Which facilities was the president talking about?'

Like kiedy to, który to can head rhetorical questions, e.g.:

(120) Która to matka nie czyni wszystkiego dla swego dziecka? (NKJP)

'Which mother would not do everything for her child?' (transl. JL-U)

The data provided in this subsection demonstrate that the presence of the segment to in wh-questions has at least two different functions: one is invalidating the ordinary interrogative reading (by converting a question into a rhetorical one, and in some instances to a thetic one) and the other is linking the wh-question to the context, while maintaining the character of

${ }^{14} \mathrm{I}$ am using the term pragmatic presupposition rather roughly here, being well aware of some difficulties associated with the term. For the purpose of this paper it is understood as the assumption on the part of the speaker about their audience's state of mind (Levinson 1983: 204).

${ }^{15}$ As opposed to copular ones, e.g. Która to działka? 'Which plot is it?' (cf. Linde-Usiekniewicz 2007, among others). 
a wh-question. ${ }^{16}$ In the latter function it resembles the impact of to added to the kind relative with jaki (see Section 3).

\subsection{The role of to after conjunctions and interrogatives pro- nouns: interim conclusion}

The observations and analyses presented in the two subsections above show that the presence of to after conjunctions introducing adverbial clauses affects them somehow similarly to relative clauses. Firstly, to acts as a presupposition trigger and, secondly, it links the content of the clause to some elements of previous discourse or audience's previous knowledge, thus indicating a pragmatic presupposition.

Only one of these phenomena is replicated in interrogatives, where to can only indicate a pragmatic presupposition. Yet in some of the interrogatives the presence of to acts in a way hitherto not found among $w h$-to bearing clauses. It converts them into either rhetorical questions or to a subtype of thetic questions.

\section{Conclusion: To in relatives, adverbials and interrogatives: function and form}

The comparison between to bearing relative clauses, adverbials and interrogatives on the one hand, vs. their to-less variants on the other, has led us to identify several functions associated with the presence of the segment to.

First of all, there is a cluster of functions associated with the presence of to in relative and pseudo-relative clauses. This cluster consists of: (a) converting all który clauses into appositive ones; (b) marking them as at-issue and not parenthetical; and (c) enhancing the grammatical acceptability of otherwise doubtful examples, by virtue of making the semantic connection between the head and the relative overriding the apparent absence of a syntactic connection (referred hitherto as ad sensu connection).

Overriding syntax in favor of semantics should be seen as yet another instance of resolving the conflict between semantics and syntax built into natural languages (Linde-Usiekniewicz 2012, 2016b, 2017). To is therefore seen as an element of semantic structure of Polish (Linde-Usiekniewicz 2012: 81-82) which encodes an ad sensu reading.

\footnotetext{
${ }^{16}$ As an anonymous reviewer rightly points out, this is also true of embedded questions, as in (i):

(i) Jestem ciekaw, który (to) koń wygrał.

'I wonder which of the horses has won.' (transl. JL-U)
} 
While the function of allowing for overriding standard syntactic patterns and enhancing acceptability in appositive relative clauses, discussed in Section 4 , is hardly controversial, it is not obvious that appositive relative clauses with internal heads:

(121) Za zasługi został nawet burmistrzem Cognac, który to urząd piastowat przez ponad 20 lat. (Mendoza 2010: 1)

'In acknowledgment of his services, he was even made the mayor of Cognac, which office he held for over 20 years.' (transl. JL-U)

(122) Widziałem wczoraj moją dawna nauczycielkę, która to nauczycielka obecnie pracuje $w$ teatrze. (Topolińska 1984: 346, cited in Mendoza 2010)

'Yesterday I saw my former schoolmistress, which schoolmistress works now in a theater.' (transl. JL-U)

are in fact a special case of the same phenomenon. The picture is clouded by the fact that there is a tendency to see the double headed relatives as prototypical, and specifically, there is a tendency to see clauses with identical external and internal heads as the standard version, and the instances of non-identity as a special case. Thus Topolińska (1984: 346) mentions the repetition of the internal head and illustrates it with identical heads; Citko (2016: 87) introduces them with the identical heads first (possibly following Cinque 2008), though she chooses non-identical heads for her example; Dobaczewski (2018: 229) only mentions internally headed relative clauses with identical heads. ${ }^{17}$ By contrast, Bańko (2013) and Mendoza (2010) focus on non-identical heads.

Yet in Linde-Usiekniewicz (in print) I argued that identical heads are mostly acceptable only when they are separated by some dependents of the external head, Topolińska's (1984: 346) example notwithstanding. Thus the standard version of double headed appositive relative clauses in Polish seems to invoke a semantic relation between the external and internal head, as can be seen in (1). ${ }^{18}$ Moreover, there are instances where in the matrix clause there is no nominal external head, and the internal one is only semantically (or in some cases derivationally as well) connected to its antecedent in the matrix clause (cf. Linde-Usiekniewicz (in print)):

(123) Najmłodsi uczestnicy fragment prozy mogli zastąpić wierszem, $z$ której to możliwości wielu uczniów skorzystało. (NKJP)

'The youngest participants were allowed to substitute a verse for a piece of prose, which [was the] option many students took.' (transl. JL-U)

(124) Konstytucja RP stanowi: Rodzice maja prawo do wychowania dzieci zgodnie z własnymi przekonaniami, a która to myśl dokładniej jeszcze formułuje zapis Powszechnej Deklaracji Praw Człowieka. (NKJP)

${ }^{17}$ This is understandable, since his book deals with repetitions.

${ }^{18}$ In Linde-Usiekniewicz (in print), I presented a typology of such semantic relations. 
'The Constitution of the R[epublic of] P[oland] states: Parents [shall] have a the right to rear their children in accordance with their own convictions, which idea is even more precisely formulated in the Universal Declaration of Human Rights' (transl. JL-U) ${ }^{19}$

The preeminence of semantics over syntax is also a feature of relative clauses introduced by kiedy and gdzie. The choice of the appropriate relativizer is semantically conditioned. Given the presence of the semantic connection between the matrix clause in internal head appositive relatives and gdzie and kiedy relatives, the purport of the relative is obligatorily at-issue, and not parenthetical to the matter at hand.

Secondly, another function of to, seen most clearly not in relative clauses but in adverbials, is that of triggering a factitive presupposition, as discussed in Subsection 7.1. This function, however, can be seen as not completely unrelated to the one associated with relative clauses. Converting a relative clause into an appositive one involves triggering a presupposition (Levinson 1983: 181). In addition, to can trigger a presupposition in a consecutive relative, without converting it into an appositive one, as seen in (95).

Thirdly, in instances of sentences that bear a semantic presupposition without to, the presence of to seems to suggest the existence of a pragmatic presupposition. That is the case of jaki kind relatives and of $w h$-questions. However, while the content and type of the semantic presupposition is easily identifiable, the content of the pragmatic presupposition suggested there is vague and may be unrelated to the content of the semantic presupposition. ${ }^{20}$

Finally, the presence of to marks some apparently wh-questions as either thetic, as in (110) presented in Subsection 7.1 or as rhetorical ones (as in (108) in the same subsection).

My claim is that although the three first cases presented above, i.e. the cluster of functions associated with converting relative clauses into appositive ones, triggering a semantic presupposition in adverbials and consecutive pseudorelatives, and encoding the existence of a pragmatic presupposition associated with a semantic one may not seem unrelated, at present I am not able to suggest what such a relation between all of them could be. In addition, there is some evidence that the pragmatic presupposition effect is unrelated to the content of the corresponding semantic presupposition and therefore I cannot argue for the presence of pragmatic presupposition in the case of appositive relative clauses. In Linde-Usiekniewicz (2017), I argued that the content of the

${ }_{19}$ The English translation of the respective wording of the Constitution is based on the official English version of the Act, available at https://www.sejm.gov.pl/prawo/konst/angielski/ kon1.htm.

${ }^{20}$ That is why I first identified the impact of to in such instances as suggesting a previous mention, and not a pragmatic presupposition. 
appositive relative clauses cannot be present in the cognitive environment of the addressee, so there is no possibility of there being any pragmatic presupposition corresponding to it. While it can still be argued, in line with Linde-Usiekniewicz (2017) that the pragmatic presupposition could concern the truth-value of the content of the relative, no such suggestion could be found in który to appositive relatives.

Yet, it could be argued, albeit tentatively, that what has been presented above as the first two cases, i.e. the appositive relatives on the one hand and the adverbials and consecutive pseudo-relatives on the other, are in fact specific instances of the same to. One way to do it is to follow the idea, presented above, that conversion of relative and pseudo-relative clauses into appositive relatives results from simply triggering a semantic presupposition and to claim that in the case of adverbials and consecutive pseudo-relatives the features presented as (b) and (c) above, i.e. semantic connectivity and at-issue-ness are present (possibly by default) in their to-less versions, and that is why there is no observable contrast in that aspect between to-bearing and to-less variants.

This reasoning reduces the first two instances, i.e. at issue appositive relative clauses, with encoded semantic connection to the matrix clause, even in the absence of a straightforward syntactic connection on the one hand, and presupposition triggering in adverbials to a single one. By the same token, to in such sentences cannot be considered a mere segment, with no other function than distinguishing to-bearing items from to-less ones. In addition, it is no longer necessary to treat the sequence który to in double headed relative clauses, e.g. (121) and (122), differently from some other to-bearing relativizers, as Mendoza (2010: 7) suggests.

In the third instance, i.e. linking with previous discourse or with some elements of the universe of the discourse, and in some cases suggesting the presence of a pragmatic presupposition, we are faced with another to: an actual linking marker (Polish: wykładnik nawiązania, rightly identified by Topolińska (1984: 346), though not in the context it appears in her example.

What remains is the to converting $w h$-interrogatives into either thetic questions or explicit rhetorical questions. My claim here is that it is none of the two to's identified so far in wh-contexts. Most likely it is the thematic to, identified by Huszcza $(1991,2000)$ and discussed in Derwojedowa and Kopcińska (2015) and in Linde-Usiekniewicz (2006, 2016a). In to-bearing declarative sentences the presence of to separates the theme or topic from focus (thus introducing the prominent theme-rheme division) and marks the theme as prominent, i.e. contrast it with all other possible themes. ${ }^{21}$ In contrast to rhematic to, mentioned in the note to example (109), which bears a contrastive falling stress,

${ }^{21}$ English translations of Huszcza’s $(1991,2000)$ Polish terminology are taken from LindeUsiekniewicz (2012: 97). 
the thematic to bears a contrastive rising pitch. A straightforward example of to bearing declarative sentence is provided in (125):

(125) Charty to[ ] szybko biegaja.

'Greyhounds do run fast.' 22

(adapted from Linde-Usiekniewicz 2016a)

For the present, I can only offer formal and phonetic identity of to in rhetorical and thetic questions and to as a marker of prominent theme as an argument towards treating them as the same phenomenon. It is yet unclear how its presence helps to override the standard division between the rhematic whword and thematic datum quaestionis part.

While the element to in thetic and rhetorical questions is a separate phonetic, stress-bearing word, it is not the case of appositive-presupposition triggering to and linking to, which both cliticize on the preceding relativizer, conjunction or interrogative word. The linking to can be considered a simple clitic (Halpern 2017), since it attaches to different kinds of words and most likely affects neither their syntactic nor their semantic properties. ${ }^{23}$ By contrast, appositive to displays some of the features associated with affixes (Anderson 2005): their semantics is idiosyncratic and so is their distribution; for example they cannot be attached to jaki degree relatives to convert them into appositives and/or trigger the factitive presupposition, yet the derivational affix vs. clitic issue remains open. However, even if they are affixes (or actually post-fixes), there is no reason to postulate just the two different lexemes który and który to, but rather a series of to-less and to-bearing relativizers and conjunctions.

\section{References}

Anderson Stephen (2005). Aspects of the Theory of Clitics. Oxford: Oxford University Press.

Bańko Mirosław (2013). Porada z dnia 5.12.2013. [https://sjp.pwn.pl/poradnia/haslo/ ktory-to;14742.htm, accessed August 12, 2018].

Buttler Danuta, Kurkowska Halina, SatKiewicz Halina (1971). Kultura języka polskiego: zagadnienia poprawności gramatycznej [Polish Grammar and Style: Grammatical Correctness]. Warszawa: Wydawnictwo Naukowe PWN.

${ }^{22}$ The English translation is and approximation. In Linde-Usiekniewicz (2006) I argued that these sentences do not correspond to so called pseudo-cleft sentences.

${ }^{23}$ Not all of them have been discussed in the present paper. The term clitic here is used in a more general sense than it is done with reference to Polish, where the term is restricted to pronominal clitics and to person and number markers, which, as an anonymous reviewer rightly points out, following Witkoś (1998), do not have a fixed position in a sentence. 
Cinque Guglielmo (1996). The pseudo-relative and acc-ing constructions after verbs of perception. In Italian Syntax and Universal Grammar, 244-275, Cambridge: Cambridge University Press.

Cinque Gugliemo (2008). Two types of non-restrictive relatives. In Empirical Issues in Syntax and Semantics 7, Olivier Bonami, Patricia Cabredo Hofherr (eds), 99-137. [http://www.cssp.cnrs.fr/eiss7/cinque-eiss7.pdf, accessed July 26, 2018].

Ciтко Barbara (2016). Types of appositive relative clauses in Polish. Studies in Polish Linguistics 11 (3), 85-85.

Derwojedowa Magdalena, Kopcińska Dorota (2015). O tak zwanych podmiotach nienominalnych. Poradnik Językowy 2, 51-65.

DobaCzewski Adam (2018). Powtórzenie jako zjawisko tekstowe i systemowe. Repetycje, reduplikacje $i$ quasi-tautologie $w$ jezzyku polskim. [Iteration as a Textual and Systemic Phenomenon: Repetitions, Reduplications in Quasi-Tautologies in Polish], Toruń: Wydawnictwo Naukowe Uniwersytetu Mikołaja Kopernika.

Grosu Alexander, LANDmAn Fred (1998). Strange relatives of the third kind. Natural Language Semantics 6 (2), 125-170.

Guz Wojciech (2017). Wh-pronoun and complementizer relative clauses: Unintegration features in conversational Polish. Studies in Polish Linguistics 11(3), 1-26.

Halpern Aaron L. (2017). Clitics. In The Handbook of Morphology, Andrew SPENCER, Arnold M. Zwicky (eds.), 101-122, Oxford: Blackwell.

HAN Chung-hye (2002). Interpreting interrogatives as rhetorical questions. Lingua $112,201-229$.

Huszcza Romuald (1986). Wykładniki uwydatnionego rematu zdania w języku polskim, japońskim, angielskim i wietnamskim. Prace Filologiczne XXXIII, 325-336.

Huszcza Romuald (1991). Wykładniki uwydatnionego tematu zdania w języku polskim, japońskim, angielskim i wietnamskim. Prace Filologiczne XXXVI, 169-181.

Huszcza Romuald (2000). Nie ma, żeby nie było - o segmentalnych wykładnikach tematyczno-rematycznej struktury zdania w polszczyźnie. Poradnik Językowy 8, 1-8.

Lauwers Peter, Willems Dominique (2011). Coercion: Definition and challenges, current approaches, and new trends. Linguistics, 49 (6),1219-1235.

Levinson Stephen C. (1983). Pragmatics. Cambridge: Cambridge University Press.

Levinson Stephen C. (2010). Pragmatyka. Warszawa: Wydawnictwo Naukowe PWN.

LINDE-UsieKNIEWICZ Jadwiga (2006). On the relative depth of cleaving. In La focalization dans les langues, Hélène Wlodarczyk, André Wlodarczyk (eds.), 81-94. Paris: L'Harmattan.

LINDE-UsieKnIEwICZ Jadwiga (2007). “Small clauses reconsidered” revisited: Not so small and not all alike, and far fewer. Lingua Posnaniensis 49,83-91.

LINDE-UsIEKNIEWICZ Jadwiga (2008). O pewnych interesujących własnościach wybranych analitycznych konstrukcji leksykalnych. In Słowo - pojęcie - tekst [Word concept - text], Renata Grzegorczykowa, Krystyna Waszakowa (eds.), 255264. Warszawa: Wydawnictwa Uniwersytetu Warszawskiego.

Linde-UsiekniewiCz Jadwiga (2012). From Conflict Through Compromise to Collaboration: Semantics, Syntax and Information Structure in Natural Languages, Warsaw: Nakładem Wydziału Polonistyki.

Linde-UsieKniewiCz Jadwiga (2016a). Kłopoty z to. Na marginesie artykułu Magdaleny Derwojedowej i Doroty Kopcińskiej, Poradnik Językowy 8, 22-34. 
LiNDE-UsieKNIEwiCz Jadwiga (2016b). A position on classifying and qualifying adjectives revisited, Studies in Polish Linguistics 11 (2), 57-84.

Linde-UsieKniewicz Jadwiga (2017). Cognitive Environment and Information Structure. In Applications of Relevance Theory: From Discourse to Morphemes, Agnieszka Piskorska, Ewa WaŁaszewska (eds.), 16-43. Newcastle upon Tyne: Cambridge Scholars Publishing.

Linde-Usiekniewicz Jadwiga (in print) Polskie zdania względne $\mathrm{z}$ wewnętrznym rzeczownikiem - wstępne rozpoznanie. Poradnik Językowy.

Mathieu Eric (2004). Discontinuity and discourse structure: Stranded nominals as asserted background topics. In Proceedings of the Dislocated Elements Workshop: ZAS Berlin, November 2003, Benjamin ShaER, Werner Frey, Claudia MAIERNBORN (eds.), 315-345. Berlin: ZAS Papers in Linguistics.

Mendoza Imke (2010). Relativsätze mit który to. Wiener Slawistischer Almanach 65, 105-118.

NKJP: Narodowy Korpus Języka Polskiego. http://nkjp.pl/ [accessed November 10, 2018]

Przepiórkowski Adam, Kupść Anna, Marciniak Małgorzata, Mykowiecka Agnieszka (2002) Formalny opis języka polskiego: teoria i implementacja [Formal Description of Polish: Theory and Implementation],Warszawa: Akademicka Oficyna Wydawnicza EXIT.

Topolińska Zuzanna (1984). Składnia grupy imiennej. In Gramatyka współczesnego języka polskiego. Składnia [Grammar of Contemporary Polish. Syntax], Maciej Grochowski, Stanisław Karolak, Zuzanna Topolińska (eds.), 301-389. Warszawa: Wydawnictwo Naukowe PWN.

Wiśniewski Marek (1990). Formalnogramatyczny opis leksemów to. 2. Słowo to w funkcji spójnika, partykuły, czasownika niewłaściwego, Acta Universitatis Nicolai Copernici XXXI, (192), 91-119.

Witkoś Jacek (1998). The syntax of clitics: Steps towards a minimalist account, Poznań: Motivex.

Jadwiga Linde-Usiekniewicz

Katedra Językoznawstwa Ogólnego, Wschodnioazjatyckiego Porównawczego i Bałtystyki

Wydział Polonistyki

Uniwersytet Warszawski

Krakowskie Przedmieście 26/28

00-927 Warszawa

jlinde(at)uw.edu.pl 
